\title{
Impact Of Asset Age/Fiscal Viability On Selected Measures Of Quality In Hospitals
}

Jim Morey, (Email: fjhm@sunyit.edu), SUNY Institute of Technology

Gary Scherzer, (Email: fgds@ sunyit.edu), SUNY Institute of Technology

Hoseoup Lee, (Email: leeh@sunyit.edu), SUNY Institute of Technology

\begin{abstract}
Seventy-three New York hospitals were examined to determine if a relationship between age of assets, fiscal viability and quality of care existed. These factors were examined for 2002 for each of the hospitals selected. Several financial variables were used to construct a fiscal viability index; and a quality index was created from selected mortality outcomes and procedural measures that may be used to measure specific aspects of institutional care. The premise that age of assets and fiscal viability will influence quality is gleaned from the Donabedian Model in which he proposed three domains important to the quality of health care. Utilizing both the financial and quality of care indices, the following statistical models were prepared: Effect of asset age on fiscal viability index, Effect of asset age on individual fiscal viability measures, and Effect of asset age and fiscal viability index on quality index
\end{abstract}

\section{INTRODUCTION}

$T$

he purpose of this study of New York State hospitals was to examine what, if any, (1) the age of assets has on a fiscal viability index, 2) the age of assets has on the specific measures used to construct the fiscal viability index, and (3) the impact age of assets and the fiscal viability index have on the quality index. The Donabedian Model (Donabedian, 1980), a sentinel work related to health care quality, defines three domains for defining and measuring health care quality. These domains are shown on Figure 1. Fiscal viability is an underlying factor that affects virtually every aspect of structure, which in turn impacts process and ultimately outcome. In general terms fiscal viability and the quality of institutional care are measures that would take some time to manifest; however, a one year snapshot would enable an assessment of a correlation. Seventy-three hospitals in New York State were chosen due to the availability of data for these hospitals for both fiscal and quality indicators.

\section{METHODOLOGY}

The methodology used the age of plant, fiscal ratios and quality data to create indexes in which we could analyze correlations. Various fiscal ratios, as outlined by Cleverly (Cleverly, 1997), were utilized to determine age of plant and to construct the fiscal viability index. These ratios are presented on Table 1. The financial ratios were "combined" into a fiscal viability index utilizing the calculated ratios of the sample hospitals. Specifically, the index was constructed using the following: Fiscal viability from Profitability: for each positive ratio, a score of .5 was assigned; and Fiscal viability from Capital Structure: for each positive ratio, a score of 1.0 was assigned. Thus, an overall fiscal viability rating for each hospital ranged from 0 (low) to 3 (high).

The quality measures employed were selected from among 25 quality measures presented by the Alliance For Quality Health Care (Alliance, 2004). The measures they presented were gleaned from New York State Health Department hospital data. The data is reported by all hospitals in New York from uniform billing forms and reported to the Statewide Planning and Research Cooperative System. The measures used to construct the index in this study are presented on Table 2. 
Figure 1: The Donabedian Model

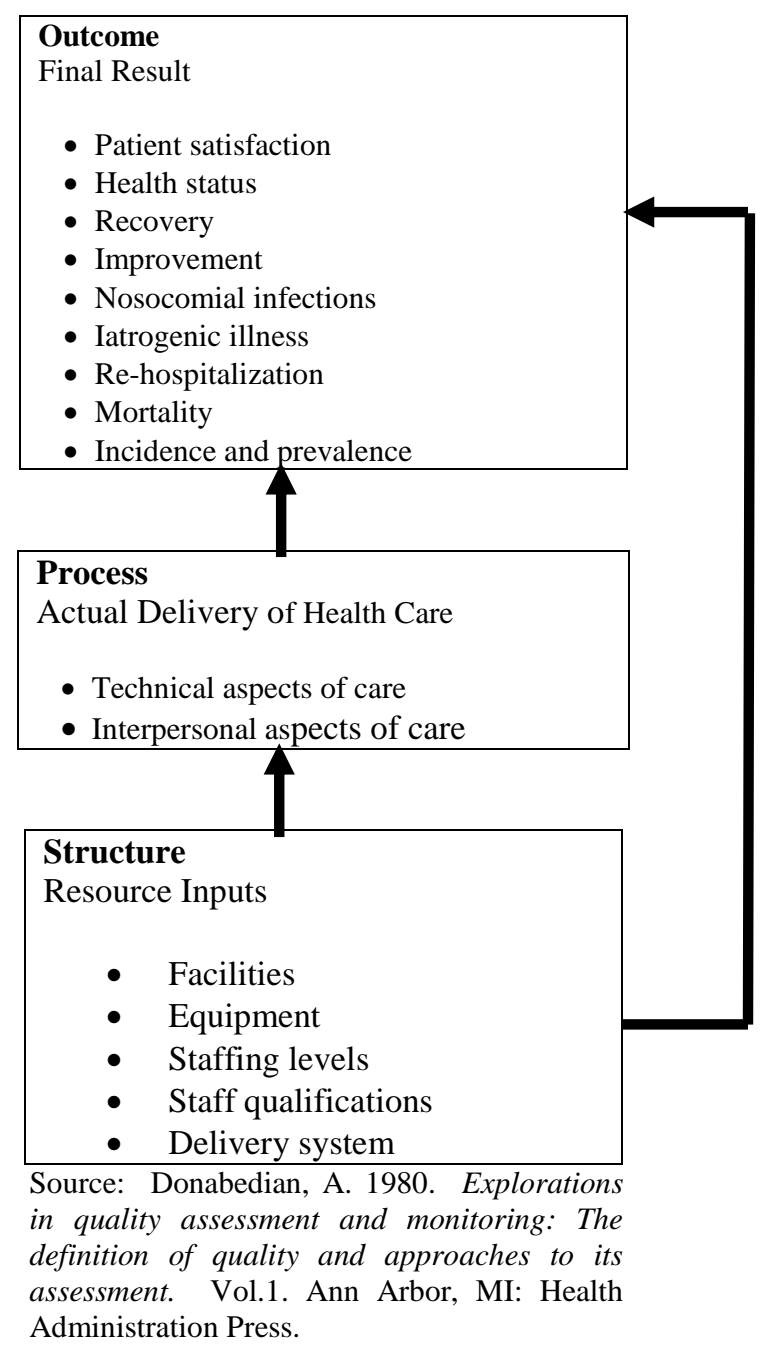

Table 1: Variables and ratios that determine age of asset and fiscal viability

\begin{tabular}{|l|l|l|}
\hline Variables & Ratio & Formula \\
\hline Age of asset & Age of asset in years & $\begin{array}{l}\text { Allowance for depreciation } \div \text { annual depreciation } \\
\text { expense }\end{array}$ \\
\hline \multirow{2}{*}{ Fiscal viability from profitability } & (1) Income margin & Net income $\div$ total operating revenue \\
\cline { 2 - 3 } & (2) Return on equity & Net income $\div$ unrestricted net asset \\
\hline $\begin{array}{l}\text { Fiscal viability from capital } \\
\text { structure }\end{array}$ & (3) Equity financing & Unrestricted net asset $\div$ total asset \\
\cline { 2 - 3 } & (4) Cash flow to debt & (Net income + depreciation) $\div$ total liabilities \\
\hline
\end{tabular}

Source: Cleverly, W.O. 1997. Essentials of Health Care Finance, Fourth Edition. Aspen Publication. 
Table 2: Quality measures of hospital inpatient care

\begin{tabular}{|c|c|}
\hline Grouping & Measure \\
\hline $\begin{array}{l}\text { Mortality For Inpatient } \\
\text { Conditions }\end{array}$ & $\begin{array}{ll}\text { - } & \text { Acute Myocardial Infarction } \\
\text { - } & \text { Congestive Heart Failure } \\
\text { - } & \text { Acute Stroke } \\
\text { - } & \text { Gastrointestinal Hemorrhage } \\
\text { - } & \text { Hip Fracture } \\
\text { - } & \text { Pneumonia } \\
\end{array}$ \\
\hline Procedure Utilization & $\begin{array}{ll}\text { - } & \text { Cesarean Section Delivery } \\
\text { - } & \text { Vaginal Birth After Cesarean Utilization } \\
\text { - } & \text { Laparoscopic Cholecystectomy } \\
\text { - } & \text { Incidental Appendectomy in Elderly } \\
\text { - } & \text { Bilateral Cardiac Catheterization }\end{array}$ \\
\hline
\end{tabular}

Source: Alliance for Quality Health Care (Niagara Health Quality Coalition.) "Indicators of Inpatient Care in New York Hospitals, 2004; www.myhealthfinder.com.

These measures were selected primarily based on their commonality. The majority of hospitals in the sample had a sufficient number of patients in each category to have their rate reported. For each measure, data was presented that compared the risk adjusted rate for that hospital with the risk adjusted State rate. If the hospital's rate was consistent with the State rate $(95 \% \mathrm{CI})$, the hospital was considered to have a rate similar to the State's. If the hospital rate was above or below the State's rate it was determined to be better or worse than the State's rate depending on the measure being assessed. Each hospital was rated in comparison to the New York State rate. They scored 2 if they were consistent with the State mean, 1 if they were significantly (95\% CI) worse than the mean, and 3 if better. These scores were then used to create an index score for the hospitals in the sample.

\section{FINDINGS}

\section{Data Analysis}

Table 3 provides descriptive statistics of variables used in this study including age of asset, fiscal viability index, and quality of hospital care index. Four variables constituting the fiscal viability index are quite volatile, especially for the return on assets and equity financing percent, justifying the conversion process used in this study. A interesting implication in this hospital sample is that the mean return on asset measure is negative. Although the median return on asset is positive, various hospitals are experiencing significantly negative return on their assets. Table 3 presents descriptive statistics for the sample

Table 3: Descriptive Statistics of 73 Hospital Sample

\begin{tabular}{|l|c|c|c|c|}
\hline Variable & N & Mean & Standard deviation & Median \\
\hline Asset age & 73 & 12.18 & 3.50 & 11.55 \\
\hline Total fiscal viability index & 73 & 2.32 & 0.89 & 3.00 \\
\hline Income margin & 73 & $0.59 \%$ & $5.6 \%$ & $0.71 \%$ \\
\hline Return on asset & 73 & $-3.76 \%$ & $46.89 \%$ & $3.19 \%$ \\
\hline Net asset equity $\%$ & 73 & $9.48 \%$ & $104.18 \%$ & $24.63 \%$ \\
\hline Cash flow over debt & 73 & $13.62 \%$ & $17.11 \%$ & $10.32 \%$ \\
\hline Quality index & 73 & 1.99 & 0.21 & 2.00 \\
\hline
\end{tabular}

Chart 1 shows the number and distribution of hospitals if they were old (greater than 1 standard deviation above the sample mean), average or young (more than 1 standard deviation below the sample mean). 


\section{Chart 1. Age of Plant by Number and Percent}
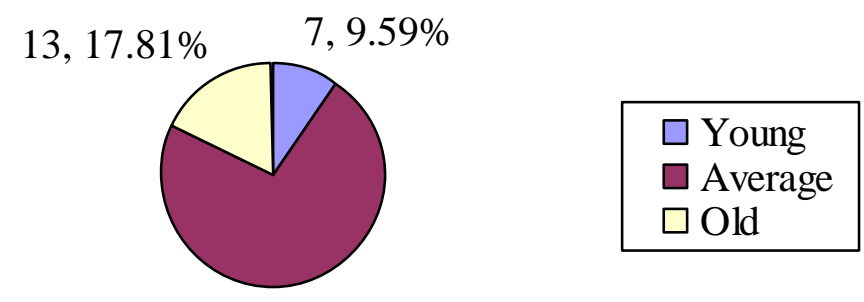

$53,72.60 \%$

Source: IRS Form 990 - 2002

Chart 2 shows the number and percent distribution of our study hospitals in terms of the fiscal viability index.

\section{Chart 2. Hospital Fiscal Viability Index by Number and Percent}

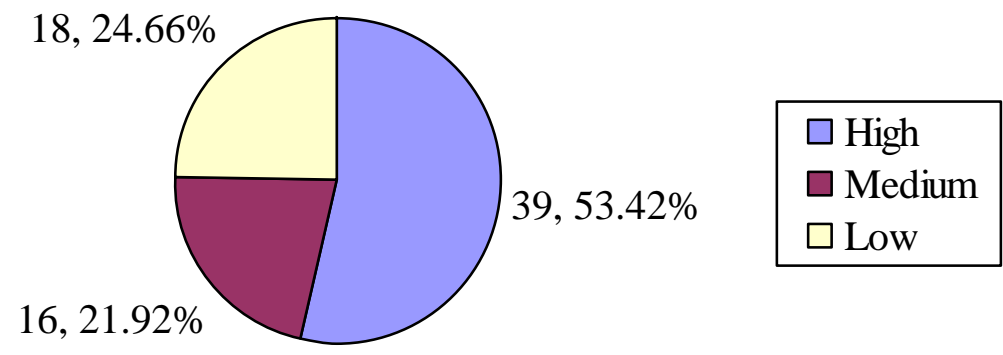

Source: Cleverly, W.O. 1997. Essentials of Health Care Finance, Fourth Edition. Aspen Publication; and IRS Form 990 - 2002

Chart 3 shows the number and percent distribution of our study hospitals for quality with high quality (greater than 1 standard deviation above the sample mean), medium or low (more than 1 standard deviation below the sample mean). 


\section{Chart 3. Hospital Quality Index by Number and Percent}

12 10

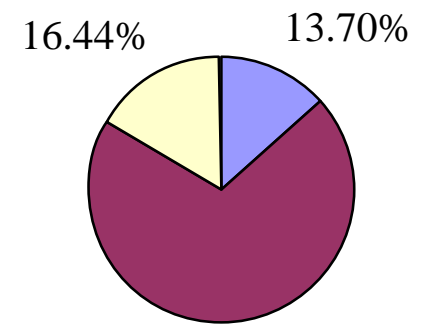

51 , $69.86 \%$

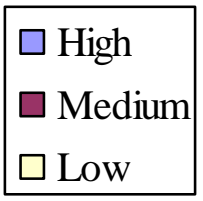

Source: Alliance for Quality Health Care (Niagara Health Quality Coalition.) "Indicators of Inpatient Care in New York Hospitals, 2004; www.myhealthfinder.com.

\section{ANALYSIS OF RESULTS}

\section{Model 1: Effect Of Asset Age On Fiscal Viability Index ( $=73)$}

The first research question of this study is whether age of assets might affect fiscal viability of the study hospitals. When a hospital provides medical care with state-of-art equipment and the latest technology, it may have a better chance to do better financially by providing high-margin procedures to its patients. Another rationale for the research expectation is that newly-built or renovated hospitals may provide more efficient care for its patients, with less labor-intensive hospital care.

As provided in Table 4, our analysis indicates that age of assets has a negative impact on fiscal viability. In other words, as long-term asset of a hospital age, the hospital may experience significantly worse financial condition. Another implication of this result is that hospitals with continuous and consistent investments in their equipments may have a greater chance to do better with respect to financial aspects of the hospital.

\section{Model 2: Effect Of Asset Age On Individual Fiscal Viability Measures (N=73)}

This part of the study examined the effect of asset age on four fiscal viability measures used for this analysis, including: income margin, return on equity, equity financing, and cash flow to debt ratios. As indicated in Table 5, only the equity financing ratio has a significant negative influence resulting from age of asset. In short, age of assets explains about $28 \%$ of the equity financing ratio. This result indicates that as a hospital operates with aging equipment and other long-term assets, the hospital tends to see a lower level of equity financing, or rely more on debt financing (deteriorating financial conditions).. 
Table 4: Effect of asset age on fiscal viability index $(N=73)$

\begin{tabular}{|l|c|c|}
\hline Variable & Coefficient & t-value \\
\hline Intercept & 3.297 & $9.04 * * *$ \\
\hline Asset age & -0.081 & $-2.80 * * *$ \\
\hline R-square & $9.94 \%$ & \\
\hline F-value & $7.84 * * *$ \\
\hline
\end{tabular}

Significance level: $* * *(1 \%)$

***Implication: This result indicates that as the age of hospital assets increase, fiscal viability of the hospital deteriorates, and its effect is significant at the $1 \%$ level. Goodness of fit measure (Rsquare) indicates that under this model, average asset age explains about $10 \%$ of fiscal viability. Thus, there is a strong correlation between asset age and fiscal viability, with a $99 \%$ confidence level for this measure.

Table 5: Effect of asset age on individual fiscal viability measures $(\mathrm{N}=73)$

\begin{tabular}{|c|c|c|}
\hline \multicolumn{3}{|c|}{ (Panel A) Effect on income margin } \\
\hline Variable & Coefficient & t-value \\
\hline Intercept & 0.038 & 1.59 \\
\hline Asset age & -0.002 & -1.40 \\
\hline R-square & \multicolumn{2}{|l|}{$2.67 \%$} \\
\hline F-value & \multicolumn{2}{|l|}{1.95} \\
\hline \multicolumn{3}{|c|}{$($ Panel B) Effect on return on asset (ROE) } \\
\hline Variable & Coefficient & t-value \\
\hline Intercept & -0.078 & -0.39 \\
\hline Asset age & 0.003 & 0.21 \\
\hline R-square & \multicolumn{2}{|l|}{$0.00 \%$} \\
\hline F-value & \multicolumn{2}{|l|}{0.04} \\
\hline \multicolumn{3}{|c|}{ (Panel C) Effect on net equity as \% of total asset } \\
\hline Variable & Coefficient & t-value \\
\hline Intercept & 2.00 & $5.26 * * *$ \\
\hline Asset age & -0.156 & $-5.21 * * *$ \\
\hline R-square & \multicolumn{2}{|l|}{$27.66 \%$} \\
\hline F-value & \multicolumn{2}{|l|}{$27.15 * * *$} \\
\hline \multicolumn{3}{|c|}{ Significance level: $* * *(1 \%)$} \\
\hline \multicolumn{3}{|c|}{ (Panel D) Effect on operating CF as \% of debt } \\
\hline Variable & Coefficient & t-value \\
\hline Intercept & 0.228 & $3.14 * * *$ \\
\hline Asset age & -0.007 & -1.32 \\
\hline R-square & \multicolumn{2}{|l|}{$2.38 \%$} \\
\hline F-value & \multicolumn{2}{|l|}{1.73} \\
\hline \multicolumn{3}{|c|}{ Significance level: $* * *(1 \%)$} \\
\hline
\end{tabular}

\section{Model 3: Effect Of Asset Age And Fiscal Viability Index On Quality Index (N=73)}

The ultimate research question of this study is to examine whether the quality of hospital care, as measured by the quality index, is affected by how old hospitals' long-term assets are and its fiscal viability. This study found that as a hospital operates with older assets and under sound financial condition, it has a greater chance to provide an acceptable quality of hospital care, as reflected by the quality of care index. 
As presented in Table 6, both age of asset and the fiscal viability index significantly explains the variability of hospital care quality (about $11 \%$ goodness of fit in this model). The fiscal viability index has about a four times greater impact on quality than age of assets. The result also indicates that fiscal viability influence positively the quality of hospital care, which means that hospitals with better financial conditions tend to provide greater quality of care to their patients. However, the effect of age of assets on quality is counter-intuitive, as the result indicates hospitals with older assets appear to provider better quality to their patients. This unexpected outcome might stem from measurement error in determining the age of asset. First, age of asset is determined with respect to all long-term assets: average age of equipment may have a greater impact on hospital care quality than that of buildings. Related to this issue, various quality measures may be affected differently with the age of assets. For example, hospitals with the latest diagnostic equipment may greatly influence the mortality of certain inpatient conditions.

Table 6. Effect of asset age $\&$ fiscal viability index on quality index $(N=73)$

\begin{tabular}{|c|c|c|}
\hline Variable & Coefficient & t-value \\
\hline Intercept & 1.627 & $12.9 * * *$ \\
\hline Asset age & 0.018 & $2.54 * *$ \\
\hline Fiscal viability index & 0.061 & $2.16^{* *}$ \\
\hline R-square & \multicolumn{2}{|l|}{$10.85 \%$} \\
\hline \multicolumn{3}{|c|}{$\begin{array}{l}\text { Significance level: } * * *(1 \%) ; * *(5 \%) \\
* * * \text { Implication: This is a mixed result. As one might assume, hospitals with good fiscal pictures } \\
\text { tend to generate a better quality index, and the effect is significant at the } 5 \% \text { level. However, } \\
\text { this result also indicates hospitals with older assets generate a better quality index (significant at } \\
5 \% \text { level, but in the opposite direction to what one might assume }- \text { as assets age, quality } \\
\text { diminishes). Goodness of fit measure (R-square) indicates that under this model, the } \\
\text { independent variables explain about } 11 \% \text { of quality index. } * * *\end{array}$} \\
\hline
\end{tabular}

This research may need further refinement of the research variables, including: various classes of long-term assets or the inclusion of a measure that considers new equipment acquisitions in the past year. Also, additional refinement with respect to hospital quality measures that are dependent on other resource inputs is needed.

\section{CONCLUSION:}

From this study, one can conclude the following:

1. As the age of hospital assets increase, fiscal viability decreases;

2. Hospitals with strong fiscal viability demonstrate strong quality indicators;

3. As the age of hospital assets increase, quality also demonstrates good results; and

4. As the age of hospital assets increase, of the four fiscal indicators utilized, only equity is impacted (positively).

Based on these conclusions, while numbers one and two were expected, number three is an unexpected outcome. This study was a one year "snapshot" of data; additional years, preferably two to three years, is necessary to refine the findings, and to determine if the above conclusions withstand the test of multi-year data. Also, refining age of assets to the level of a hospital's technology expertise and human expertise will assist in further explaining number three. Numerous factors influence the quality of care in a hospital as presented in Figure 1, and it is difficult to specifically attribute fiscal viability to quality. However, the evidence is compelling that the fiscal health of an organization will directly affect the outcomes of hospital care.

\section{REFERENCES}

1. Alliance For Quality Health Care (Niagara Health Quality Coalition.) "Indicators of Inpatient Care in New York Hospitals, 2004; www.myhealthfinder.com

2. Cleverly, W.O. 1997. Essentials of Health Care Finance, Fourth Edition. Aspen Publication. 
3. Donabedian, A. 1980. Explorations in quality assessment and monitoring: The definition of quality and approaches to its assessment. Vol.1. Ann Arbor, MI: Health Administration Press.

4. “IRS Form 990” for year 2002; www.Guidestar.org

\section{NOTES}

